This is a self-archived version of an original article. This version may differ from the original in pagination and typographic details.

Author(s): Alajoutsijärvi, Kimmo; Kettunen, Kerttu; Sohlo, Sauli

Title: Shaking the Status Quo : Business Accreditation and Positional Competition

Year: 2018

Version: Published version

Copyright: @ Academy of Management Learning \& Education, 2018.

Rights: In Copyright

Rights url: http://rightsstatements.org/page/lnC/1.0/?language=en

Please cite the original version:

Alajoutsijärvi, K., Kettunen, K., \& Sohlo, S. (2018). Shaking the Status Quo : Business Accreditation and Positional Competition. Academy of Management Learning and Education, 17(2), 203-225. https://doi.org/10.5465/amle.2015.0199 


\title{
SHAKING THE STATUS QUO: BUSINESS ACCREDITATION AND POSITIONAL COMPETITION
}

\author{
KIMMO ALAJOUTSIJÄRVI \\ University of Jyväskylä, Finland and University of Agder, Norway \\ KERTTU KETTUNEN \\ University of Turku, Finland \\ SAULI SOHLO \\ University of Oulu, Finland
}

\begin{abstract}
Modern business schools exist in a complex world of rankings, ratings, and credentials. Some argue that in increasingly competitive global higher education markets, signaling status and quality has actually become more important than having them (Gioia \& Corley, 2002; Trank \& Rynes, 2003). For many contemporary business schools, international accreditations have become key means and first steps in pursuing legitimacy and global status. In this essay, we elaborate in detail on a business school's international accreditation process, including its motivations and outcomes. We conclude that while accreditation processes are, at best, fruitful quality improvement exercises, the inherent motivations stemming from the urge for organizational legitimacy, status, and reputation should not be overlooked by either the accrediting agencies or business schools themselves. Ironically, while accreditation agencies (AACSB and EQUIS are those focused on here) rarely explicitly encourage competition, their exclusivity seems to generate it between schools that aspire to belong to "the club." For schools that gain access to the process, this means that on the flip side of the happy and collaborative jump in quality there is a much more serious demarcation and revealing redefinition of the accredited entity's future supporters, collaborators, partners, and competitors.
\end{abstract}

The global expansion of business schools and the triumphal march of their accrediting agencies are inseparable (Durand \& McGuire, 2005). Put simply, globalization has lowered both visible and invisible barriers between nationally regulated education systems. Upon the gradual disappearance of the "old system," students, faculty, and recruiters are increasingly facing the challenge of sorting the wheat from the chaff of the business school field. A new order to the multiformity of institutions that exists at the global level is being created by those capable of instilling much-needed simplicity and certainty in the evaluation process. This opportunity has been most successfully seized by two continuously expanding accrediting agencies, AACSB (The Association to Advance Collegiate Schools of Business) and EQUIS (EFMD Quality Improvement System, awarded by the European Foundation for Management Development). In past decade, these two organizations have become the most desired and most valuable recognitions of management education excellence (Zammuto, 2008; Guillotin \& Mangematin, 2015). In particular, the U.S.-based AACSB International has gained an overwhelming global presence, currently accrediting over 800 business schools in over 50 countries (AACSB, 2011, 2018a, 2018b).

According to their mission statements, both AACSB and EQUIS are service providers that set the advancement of management education as their main purpose. Phrased in their own words, AACSB "encourages and accelerates innovation to continuously improve business education" (AACSB, 2016a), while the fundamental objective of EQUIS, linked to the mission of EFMD, is to "raise the standard of management education worldwide" (EFMD, 2016). In support of these aims, AACSB and EQUIS provide business schools with well-developed standard frameworks, detailed quality manuals, and informal networking benefits, such as benchmarking opportunities and sharing of best practices. 
The global expansion of the accreditation business, however, is hardly explained by schools' burgeoning enthusiasm for the quality gospel. On the contrary, business schools' motivations for seeking accreditations are often far more focused on obtaining the AACSB/EQUIS label than on the development process involved. As noted by Zammuto (2008: 263-266) and Lejeune and Vas (2014: 109), accreditation agencies act as powerful legitimating bodies that, through certification, enhance status and reputation, and thus competitive advantage, both domestically and globally. For an accreditation-seeking business school, an AACSB and/or EQUIS certificate provides entrance to the rather exclusive "club" that facilitates their association with the most prestigious business schools worldwide (McKee, Mills, \& Weatherbee, 2005; Thomas, Billsberry, Ambrosini, \& Barton, 2014; Juusola, Kettunen, \& Alajoutsijärvi, 2015). At the same time, accreditations act as trusted signaling devices that can reassure others of the school's appropriateness, performance, and quality (Romero, 2008).

In a more critical vein, the business school accreditation race has begun to resemble "keeping up with the Joneses." What has already been witnessed, for instance, in the AACSB-saturated US, Canada, and France, is that the more accredited business schools there are in a certain country, the more difficult it becomes to gain competitive advantage through accreditation (Thomas et al., 2014). In other words, achieving accreditation has become the de rigueur "precursor for international competition" (Thomas et al., 2014), resulting in an accreditation race where more than onepreferably the "triple crown": AACSB, EQUIS, and AMBA, The Association of MBAs accrediting MBA programs only-accreditation is needed. What becomes a norm is that no nonaccredited school enjoys a strong position in any established business school ranking, and the lack of a major quality credential appears to quickly turn into a handicap that creates upstairs and downstairs tiers of business schools (Lejeune \& Vas, 2014; Blanco Ramírez, 2015; Juusola, Kettunen, \& Alajoutsijärvi, 2015). With the continuing expansion of both AACSB and EQUIS into new, underrepresented countries, it becomes increasingly relevant to consider how the competitive dynamics of business schools at regional, national, and local levels are affected by international accreditations (Scherer, Rajshekhar, Bryant, \& Tukel, 2005).

\section{UNRAVELING THE ACCREDITATION RACE}

We argue that business schools' initial accreditation endeavors are motivated first by competition, and only second by quality improvement. To understand the accreditation race, we must understand the fundamental nature of competition among the institutions striving to become accredited. In unraveling this competition, we stress that the rivalry between business schools (or any other types of higher education institutions, for that matter) is positional in nature (Hirsch, 1976). In other words, business school competition is positional competition, because their primary offering, a business degree, is a positional good: For prospective students and alumni, the value of a business degree comes from the social status and career prospects that it creates in relation to other, competing alternatives (Marginson, 2006; Adler \& Harzing, 2009). Accreditations are valuable because they award business schools legitimacy (being part of an exclusive club with the world's top business schools), status (potentially higher ranking placement or access to the rankings in the first place), and reputation (an independent proof of high performance and quality) that are at least partly transferable to the students, alumni, faculty, and other stakeholders affiliated with an accredited institution.

Despite the clear implications of international accreditations for competition between business schools, this perspective has rarely been addressed in the previous literature (exceptions include, e.g., Thomas et al., 2014; Guillotin \& Mangematin, 2015). We aim here to fill this gap. We ask, "How does international accreditation affect business school competition?" Our contribution is a conceptual framework that explicitly identifies business schools' motives for seeking initial accreditation as well as the impacts of the accreditation process on striving for prestige.

The essay proceeds as follows: First, we provide a review of extant studies on business school accreditation. We show that despite the growing body of literature discussing the implications of accreditation agencies on the business school field in general, the extant literature has largely neglected discussing accreditations from the standpoint of an individual, accreditation-seeking business school.

Second, we argue that positional competition is essentially a competition over positive social judgments: The higher the ranking a business school desires in relation to its competitors, the more positive must be the evaluators' (peer schools, the media, corporate partners, prospective students, faculty, alumni, etc.) judgments of the school's legitimacy, status, and 
reputation (Bitektine, 2011; Bitektine \& Haack, 2015). The opportunities for an individual business school to influence its legitimacy, status, and reputation judgments on the basis of improved teaching quality or research performance are often fairly limited, costly, and time-consuming (Iñiguez de Onzoño, 2011: 69-71). The beauty of a successful AACSB or EQUIS accreditation endeavor is that as a single project, it is likely to have a relatively rapid, positive influence on judgments in all three dimensions (Iñiguez de Onzoño, 2011: 117; Lejeune \& Vas, 2014).

Third, the essay proceeds to a description and analysis of the accreditation process of the Finlandbased Oulu Business School (OBS). The timeperiod under scrutiny is 2006 to 2016. This revelatory single-case study (data and methodological choices are explained in the Appendix A) allows the opportunity to observe the process of international accreditation in a context that is relatively new to accreditations and to elaborate on a lower ranked business school's effort to improve its competitive position through recognition by an international accreditation agency. While addressing the issues of business school legitimacy, status, and reputation, it is necessary to accept that the judgments regarding all three aspects occur simultaneously at multiple levels: local, national, and global (Winston, 2000; Marginson, 2006). Therefore, recognizing that at the local level business schools often operate within multidisciplinary universities, we adopt a four-level approach, viewing positional competition as an interplay among the global, national, university, and business-school levels. After the analysis of the OBS case, we evaluate the impact of the accreditation process on the school's legitimacy, status, and reputation at all levels. Last, we present our conclusions and discuss the implications of our findings for the business school field more broadly.

\section{RESEARCH ON BUSINESS SCHOOL ACCREDITATIONS}

Within the extant body of academic literature on business school accreditations, accreditation standards' changes have gained most of researchers' attention. This stream of literature has primarily explored the changes in standards of the AACSB (the most long-standing accreditation agency established which was in 1916 as a business school association of 18 U.S. business schools) that have emerged as the agency has responded to competitive pressures stemming from the creation of new accreditation agencies in the US, such as the Accreditation Council for Business Schools \&
Programs (ACBSP) and the International Assembly for Collegiate Business Education (IACBE) in 1988 and 1997, respectively, and in Europe, such as EQUIS in 1998 (see, e.g., Casile \& Davis-Blake 2002; Roller, Andrews, \& Bovee 2003; Durand \& McGuire 2005).

The emergence of new agencies has changed the competitive dynamics of the field, imposing more flexible standards and challenging AACSB's exclusivity to grant accreditations in the US. In particular, the 1991 Standards change and the transition of AACSB to a mission-based system irritated numerous academics from research-oriented institutions, who criticized the lowering of entry criteria to allow mediocre, more teaching-oriented institutions to join the club (McKenna et al., 1995; Henninger, 1998; Jantzen, 2000; Yunker, 2000). For instance, Yunker (2000) criticized AACSB for lumping all accredited institutions together, making it impossible to assess how well (or poorly) the minimum criteria had been exceeded. Because teaching effectiveness is more difficult to assess than research output, Yunker (2000) suggested that AACSB should issue Certifications of Distinction to a minority of business schools that maintain very high research productivity. As a response to the criticism of the mission-linked system, the 2003 Standards change focused particularly on measuring and assuring teaching excellence (Miles et al., 2004; Pringle \& Michel, 2007; Moskal et al., 2008; LaFleur et al., 2009; Pesta \& Scherer, 2011).

In the history of accreditations, AACSB's Standards' changes represent milestones in the entire field. In response to the corporate scandals and financial crises that have inspired a number of critical commentaries questioning the raisons d'être of business schools, scholars have also demanded that AACSB adopt a more prominent role as a prescribing and auditing body in the establishment and maintenance of standards for business school responsibility (see, e.g., Swanson 2004; Podolny 2009). The latest landmark that is setting the scene for the next chapters of business school development are the 2013 Standards, which impose on business schools the burden of more clearly articulating their engagement with issues of ethics, social responsibility, and sustainability (Cooper et al., 2014).

The second stream of accreditation studies focuses on the institutional development of accreditation agencies, emphasizing their expansion and internationalization (Roller et al., 2003; Durand \& McGuire; 2005; Scherer et al., 2005; Flesher, 2007; Zammuto, 2008; Thomas et al., 2013). Both AACSB and EFMD have had their "authorized" histories and promotional puffs published, which describe the timelines, past achievements, and future challenges of both accreditation 
agencies (Flesher, 2007; Trapnell, 2007; Urgel, 2007; Thomas et al., 2013). In a more independent vein, Durand and McGuire (2005) discussed the paradox between accreditation agencies' attempts to expand their domain while maintaining their legitimacy among their existing constituents. In fact, after reaching a "saturation point" among U.S. business schools in the 1990s, AACSB began to seek opportunities for expansion into the neighboring countries of Canada and Mexico. The real leap toward internationalization, however, occurred in 1997, when it accredited its first European business school, ESSEC in France, after which a number of top-tier institutions followed. Durand and McGuire (2005) argued that upon its international expansion, AACSB had to adapt its values and processes to the new foreign business school systems while simultaneously trying to maintain its legitimacy among its extant accredited institutions in the US.

The third and last identified stream of accreditation studies focuses on accreditation from a process perspective, stressing the motives, obstacles, pros, cons, and unintended consequences of achieving business school accreditations (Harvey, 2004; McKee et al., 2005; Scherer et al., 2005; Helms Mills et al., 2006; Julian \& Ofori-Dankwa, 2006; Romero, 2008; Zammuto, 2008; Elliott, 2013). In a more critical vein, some (Dillard \& Tinker, 1996; Bell \& Taylor, 2005; Lowrie \& Willmott, 2009) have argued that accreditations are inherently bad practices. For instance, Harvey (2004) claimed that accreditation processes are by no means benign or apolitical, but represent a power struggle that impinges on academic freedom while imposing an extensive bureaucratic burden. Furthermore, accreditations have been criticized for restraining innovation and running counter to pedagogic improvement processes (Julian \& Ofori-Dankwa, 2006). From the international perspective, the AACSB in particular has been accused of ethnocentrism and insensitivity to cultural diversity, thereby forcing schools around the world to conform to the American elite business school model (Cavaliere, Glasscock, \& Sen, 2014).

\section{POSITIONAL COMPETITION: LEGITIMACY, STATUS, AND REPUTATION}

The growing influence of international accreditations on business schools (be it about standards changes, accreditation agencies' growth aspirations, or practices and models they impose on business schools) is symptomatic of the type and intensity of competition that occurs in the field.
Placed in the wider discourse of higher education, the competition between business schools is most appropriately described as positional competition that follows a different logic than traditional market competition (Hirsch, 1976; Frank, 1999; Winston, 2000, 2004; Marginson, 2006, 2013; Hazelkorn, 2014; Alajoutsijärvi, Juusola, \& Lamberg, 2014). As Marginson (2013: 364) observed, "Unlike textbook markets, where there is no intrinsic barrier to producer pluralization, in status competition in higher education, the number of top producers is largely fixed." Thus, positional competition among business schools is limited by the number of positions available within a specific ranking system: Only one business school can occupy each rank, and only 100 business schools can be included in the top 100 . For instance, one of the best-known global ranking schemes, the Financial Times Global MBA Ranking, lists the top-100 MBA programs worldwide. Conversely, national business school ranking systems are typically limited to listing the top-10 or 20 institutions in a particular country. Regardless of the ranking system applied, a school's position in any listing directly affects the relative positions available to its competitors (Hazelkorn, 2014; Marginson, 2013). Furthermore, as a result of positional competition, the business school elite that occupies the highest positions in any ranking system is typically self-reproducing, creating a status quo that is extremely difficult for new entrants to disrupt (Winston, 2000, 2004).

\footnotetext{
"Business school competition is positional competition, because their primary offering, a business degree, is a positional good: For prospective students and alumni, the value of a business degree comes from the social status and career prospects that it creates in relation to other, competing alternatives (Marginson, 2006; Adler $\&$ Harzing, 2009)."
}

In essence, positional competition between business schools is a competition over better and more positive judgments regarding the school's legitimacy, status, and reputation, which, in aggregate, could lead to higher placement in a desired ranking scheme. As emphasized for instance by Bitektine (2011), legitimacy, status, and reputation are not assets that can be directly acquired, possessed, or lost by an organization (cf. Vidaver-Cohen, 2007: 299 reputational capital; Rindova et al., 2005; 2010); instead, they are based 
on social judgments made by their evaluating audiences (see also, Bitektine \& Haack, 2015). Hence, the position of a business school in any ranking scheme depends on the types of social judgments made by its peer schools, the media, corporate partners, prospective faculty, students, and other stakeholders.

In line with Bitektine (2011), evaluations of legitimacy, status, and reputation involve different judgment formation processes that take place either alone or in different sequences and combinations. The form of judgment(s) selected by the evaluator(s) is likely to have important consequences for the organization being evaluated: The judgment type dictates, for instance, the extensiveness of the search for information regarding the organization, as well as the level of "rationality" involved, or the number of shortcuts taken in the evaluation process (Bitektine, 2011). Hence, the judgment type(s) influences both the length and the depth, as well as the final outcome of the decision-making process.

When a legitimacy judgment is made, the evaluation is about the organization's right to exist in the first place: Legitimate institutions attract continuous support and resources, whereas, illegitimate ones do not. The importance of legitimacy is derived from its impact on institutional continuity, which is dependent on whether its constituents consider the organization to be either acceptable or unacceptable based on two types of legitimacy judgments (Bitektine 2011). First, in a cognitive legitimacy judgment, evaluators' decisions about legitimacy involve an assessment of whether the organization belongs to an existing, known, and unproblematic category or group whose legitimacy has already been confirmed. Second, a sociopolitical legitimacy judgment involves a more in-depth evaluation and scrutiny of the organization's form, processes, and outcomes in relation to the prevailing social norms and regulations. In the context of management education, where a degree awarded by a business school does not guarantee exclusive access to the profession of management (see, e.g., Khurana 2007), selecting a school is, from prospective students' perspective, an evaluation process associated with high uncertainty and high economic and social stakes. Therefore, it is in the interest of most business schools to become cognitively associated with a socially accepted and attractive group of institutions to avoid further scrutiny and possible questioning of their legitimacy. In the increasingly global market of business schools, major accreditation agencies (AACSB and EQUIS) appear as "shortcuts" in the legitimacy evaluation process: They relieve the burden of high uncertainty and the need for extensive information searches for their prospective students, faculty, recruiters, and partner organizations by allowing them to use accreditations gained (or not gained) as a criterion for shortlisting.

As opposed to the dichotomous nature of legitimacy judgments (i.e., acceptance/nonacceptance decisions), status considerations involve ordinally arranging the legitimate institutions under scrutiny into multiple status groups (Bitektine, 2011; Suchman, 1995). Although the legitimacy judgment of a business school emphasizes the similarity of that school to its reference group, status judgments underline the differences between the schools in the same reference group, requiring the evaluator to determine where a particular business school fits in the ranked order of its peers (see, Bitektine, 2011: 163). Status in itself is a product of a business school's academic heritage, prestige, deference, power, and social influence (Ridgeway \& Walker 1995). Therefore, status judgments form the basis of a relatively permanent rank ordering that exists among business schools (Piazza \& Castellucci, 2014).

Last, in reputation judgments of business schools, attention is directed toward the school's recent actions and performance to anticipate its future behavior. Initial accreditations have exactly this type of due diligence: A trustworthy and respected external body evaluates the essential quality characteristics of a business school. Hence, as opposed to legitimacy and status judgments, the focus of reputation judgments is on identifying the unique features of the school. Building on Weber (1978), Washington and Zajac (2005) clarified the distinction between status and reputation by arguing that while the former captures differences in agreedupon social ranks that generate privileges that are not directly related to performance, the latter captures differences in quality that generate performancebased outcomes. In other words, while established status orderings, such as business school rankings, are typically rigid and slow to change, reputationrelated evaluations occur on a continuous basis and are, therefore, more sensitive to short-term changes in a business school's quality or performance (Piazza \& Castellucci, 2014).

Controversially, based on the notion of the three different forms of social judgments, it matters greatly 
for a business school to focus not only on improving quality and performance (and ensuring positive reputation judgments), but also to aim for better judgments regarding legitimacy and status, which are likely to direct the school's attention more toward accreditations and rankings. On the flip side of the accreditation coin, however, are the high stakes in terms of reputation and status for those that fail to become accredited (Lejeune \& Vas, 2014). Still, being part of a "club" and ranking high are goals worth pursuing. This is particularly true because of the likely shortcuts taken by the important, but information-overloaded evaluators, who might not get as far as actual performance evaluation in their decision-making processes. In other words, differentiation between legitimacy, status, and reputation judgments is needed to explain the accreditation race as a form of business school competition: Contemporary business schools are increasingly faced by a situation where to survive, they cannot afford to lose sight that at every level of scrutiny, social judgments about them are being formed.

\section{OUR CONCEPTUAL FRAMEWORK}

Table 1 depicts our conceptual framework, which explicitly identifies a business school's motives for seeking initial accreditation and provides a tool for analyzing the impacts of the accreditation process. The framework consists of 12 cells that differentiate between legitimacy, status, and reputation judgments and identify the different levels (global, national, university, and business school) where these are made. As an example, legitimacy at the global level is determined by a business school's membership in the category of accredited schools, whereas at the national level, the legitimacy question merely concerns whether the business school is a legitimate, degree-granting institution. This legitimacy is, in many countries, granted by the nation-state and its ministry of education. At the university level, conversely, legitimacy depends on whether the school is recognized as an independent unit, that is, a faculty or a school that has a dean who reports directly to the headquarters. The university business school governance structure, including financial relationships and strategic independence, also needs to be explicated when applying for AACSB or EQUIS eligibility (see, e.g., AACSB, 2015). Last, at the business school level, institutions are generally considered to be full-service schools when they offer undergraduate, graduate, doctoral, and executive education programs in business (see, e.g., Iñiguez de Onzoño, 2011: 69-71). Although accreditation agencies generally do not require business schools to have full-service status, they do establish explicit program inclusion-exclusion criteria to ensure that the accredited entity has control over the business programs that could be associated with it (AACSB, 2015).

\footnotetext{
"In other words, differentiation between legitimacy, status, and reputation judgments is needed to explain the accreditation race as a form of business school competition: Contemporary business schools are increasingly faced by a situation where in order to survive, they cannot afford to lose sight that at every level of scrutiny, social judgments about them are being formed."
}

In terms of status, an evaluator making a judgment determines where the organization fits in the ranked order of similar organizations in the global and national fields of business schools, or evaluates how the business school ranks among the faculties of its mother university or how the individual departments

TABLE 1

Research Framework

\begin{tabular}{|c|c|c|c|}
\hline & Legitimacy & Status & Reputation \\
\hline $\begin{array}{l}\text { Global (judged in relation } \\
\text { to business school field) }\end{array}$ & $\begin{array}{l}\text { Accredited business } \\
\text { school category }\end{array}$ & $\begin{array}{l}\text { Ranking among accredited } \\
\text { business schools }\end{array}$ & $\begin{array}{l}\text { Relative performance among } \\
\text { accredited business schools }\end{array}$ \\
\hline $\begin{array}{l}\text { National (judged in relation } \\
\text { to university-based business } \\
\text { schools in the same country/region) }\end{array}$ & $\begin{array}{l}\text { Degree-granting business } \\
\text { school category }\end{array}$ & $\begin{array}{l}\text { Ranking among degree-granting } \\
\text { business schools }\end{array}$ & $\begin{array}{l}\text { Relative performance among } \\
\text { degree-granting business } \\
\text { schools }\end{array}$ \\
\hline $\begin{array}{l}\text { University (judged in relation } \\
\text { to schools within the university) }\end{array}$ & $\begin{array}{l}\text { University school/faculty } \\
\text { category }\end{array}$ & $\begin{array}{l}\text { Ranking among university } \\
\text { schools/ faculties }\end{array}$ & $\begin{array}{l}\text { Relative performance among } \\
\text { university schools/faculties }\end{array}$ \\
\hline $\begin{array}{l}\text { Business school (judged in } \\
\text { relation to departments } \\
\text { within the school) }\end{array}$ & $\begin{array}{l}\text { Full-service business } \\
\text { school category }\end{array}$ & $\begin{array}{l}\text { Ranking among business } \\
\text { disciplines/departments }\end{array}$ & $\begin{array}{l}\text { Relative performance among } \\
\text { departments }\end{array}$ \\
\hline
\end{tabular}


(which are typically discipline-based) are ranked within the business school (see Bitektine, 2011: 163). The final element of reputational judgment involves an evaluation of the business school's relative performance (e.g., research output, degree production, and financial performance) with respect to its reference groups at the global, national, and university levels, as well as within the business school's internal structures, such as discipline-based departments.

\section{SETTING THE SCENE: BUSINESS SCHOOLS IN FINLAND}

In Finland, all universities are state-accredited. The traditional universities (15 altogether) are research-based institutions that offer degrees from the undergraduate to doctoral levels. Of the 15 research universities, 10 have a business school. For reasons that are practical (e.g., universities are state-funded); political (e.g., the role of universities with regard to regional development and well-being is widely recognized); and value-based (e.g., education is understood as a public good), the Finnish higher education system is very egalitarian. Currently, equal access to higher education applies to both Finnish and other EU nationals, from whom Finnish legislation prohibits schools from collecting tuition fees.

In management education, the 10 university-based business schools form a tightly knit, cooperative, and collegial network of institutions and scholars (Alajoutsijärvi, Kettunen, \& Tikkanen, 2012; Kettunen, 2013). Consequently, many collaborative arrangements, such as national-level graduate schools and joint entrance examination systems, exist among the business schools, and no systematically conducted, formal business school ranking has been created at the national level. Nevertheless, a relatively strong implicit pecking order among business schools exists and has arguably become steeper over the past decade. Traditionally, a school's position in this unofficial ranking system depends on its age, size, and location. These factors contribute to the schools' prestige, deference, power, and social influence and create the basis for the national business school hierarchy.

Illustrative of this observation is that the two oldest capital-city-based business schools in Finland (Aalto University School of Business, formerly known as Helsinki School of Economics, and Hanken, the Swedish School of Economics, established in 1911 and 1909, respectively) continue to be perceived as Finland's top business schools (Mikkonen, 2012; Kettunen, 2013; Juusola, Kettunen, \& Alajoutsijärvi,
2015; Sihvonen \& Vähämaa, 2015). Besides their strong positions nationally, these institutions have also become increasingly well-known internationally, being able to participate in the global business school reputation race. Furthermore, their positions have been solidified by international accreditations and increased private-sector endowments made possible to Finnish universities after 2010 legislation change (Aalto received an initial EQUIS accreditation in 1998 and AACSB in 2007, whereas Hanken received an initial EQUIS accreditation in 2000, and AACSB in 2015) (Kettunen, 2013).

Whereas the "top" schools have been fixed for more than 100 years, the division of the ranking positions below them is less obvious. What is evident is that the lowest ranks are typically occupied by the youngest and most peripherally located institutions. Furthermore, in the mid-1990s, Finland created a system of polytechnics that began to offer undergraduate business education and to confer degrees in business administration (currently, there are approximately 25 institutions altogether, of which most offer business programs). Initially, these institutions were created based on a political initiative, to be operated on a regional basis, and in close cooperation with local business communities. Despite claims of differences between the missions of traditional research universities and polytechnics, in reality, the polytechnics began to quickly assimilate into universities and compete with them by labeling themselves as universities of applied sciences. By the mid-2000s, however, the polytechnics even began to offer master's degree programs. As an outcome of the expansion of business education, the competitive dynamics in the Finnish higher education field changed, creating substantial pressures, especially for the youngest university-based business schools that have less obvious status to differentiate themselves from the polytechnics.

\section{OULU BUSINESS SCHOOL'S ACCREDITATION PROCESS, 2006-2016}

\section{Business School in Oulu: The Youngest of the Youngest (2006-2007)}

Initially a small economics and business studies department within the Faculty of Technology at the University of Oulu, Oulu Business School was born in the context of an increasingly populated business school sector in Finland. The authority to confer business degrees was granted to University of Oulu (hereafter UofO) by the Ministry of 
Education in 1991, shortly before the nationwide system of polytechnics was created. In 2000, Oulu Business School's (hereafter OBS) department status within the UofO was upgraded to an actual business school, which put OBS formally on par with the university's other faculties. The establishment of OBS represented Finland's northernmost business-degree-granting institution. For a number of years to come, OBS was the youngest, and viewed from Helsinki-the center of gravity of Finland's economic life-the most peripherally located business school in the country. Within the technology, science, and medicine emphasis of the UofO, OBS was the youngest, smallest, and most modestly resourced school, and by 2005 its share of the university's state budget allocated to faculties was only 3.4\% (approximately EUR 3.4 million, see Figures 1 and 2).

Admittedly, however, the Nokia-driven technology city of Oulu provided favorable and wealthy surroundings for a new business school. Attracting students mainly from the northern part of Finland, the period from 2000 to 2005 was a period of growth for OBS. During this time, the number of students increased from 650 to 1000, and the faculty and staff from 40 to 70 . Despite OBS's success in producing undergraduate and graduate degrees, building a serious research institution was a time-consuming task. This difficulty was reflected in the relatively low levels of publications and doctoral degrees produced in the early years. On the other hand, a strong teaching emphasis was very much expected from OBS by the UofO. What was considered important both regionally and nationally was not business degrees per se (Finnish industry has traditionally favored employing engineer-managers; see, e.g., Aspara et al., 2011), but the business school's potential to facilitate the commercialization of technological innovations. One way to accomplish this was, in UofO's vision, through offering business minor studies for students in engineering and IT.

Despite successfully leveraging its regional growth potential, OBS was, at the outset, a no-name business school with little recognition at the national, not to mention the global, business school spheres. Therefore, it took many years of ramping up degree production, publication activities, and international connections before the size and volume of OBS allowed any introduction of international accreditation as part of its future plans. When a new dean was appointed in 2006, however, EQUIS and AACSB standards were adopted as the guiding principle of his leadership agenda. Recognizing the status-enhancing impact of international accreditations on the two already accredited top schools in the country (Aalto and Hanken), the new dean argued to the OBS management board that something should be done to raise the school from its perpetual underdog position. Indeed, although none of his colleagues expressed it directly, it appeared to be almost an unwritten rule that in university-level budget allocation negotiations and at national-level business school gatherings and deans' meetings, the representatives of "provincial business schools" were rarely invited to the VIP tables and speakers' podiums. Despite the progress shown based on several performance indicators, in the invisible league table of business schools, despite the dean's regrets, OBS was not only the youngest of the youngest, but also the lowest of the lowest (see Table 2 for an illustration of

FIGURE 1

OBS's Funding 2005-2016

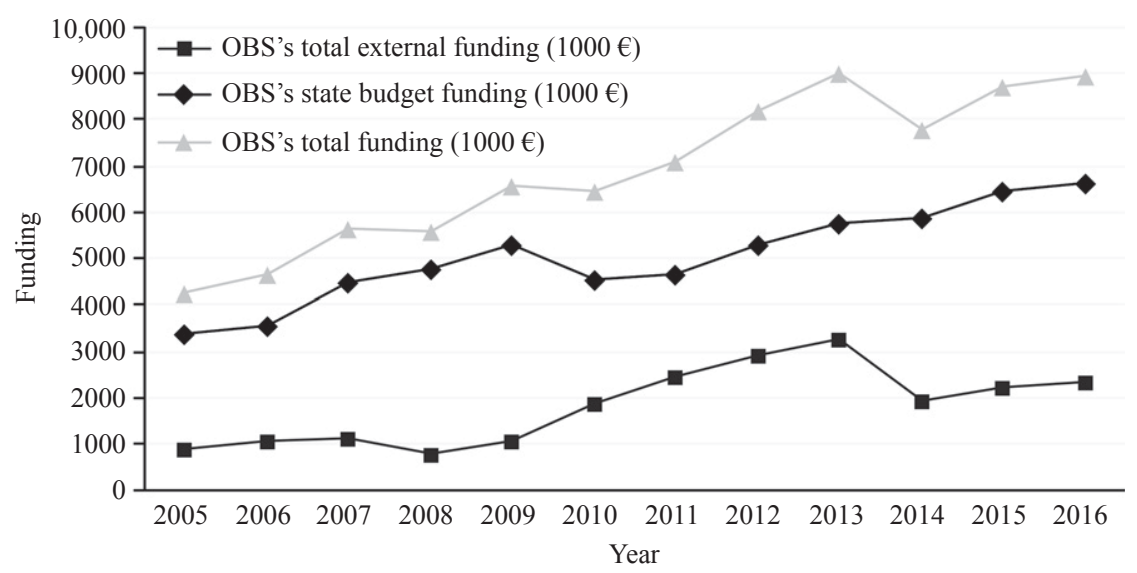


FIGURE 2

\section{OBS's Share of UofO State Budget Funding}

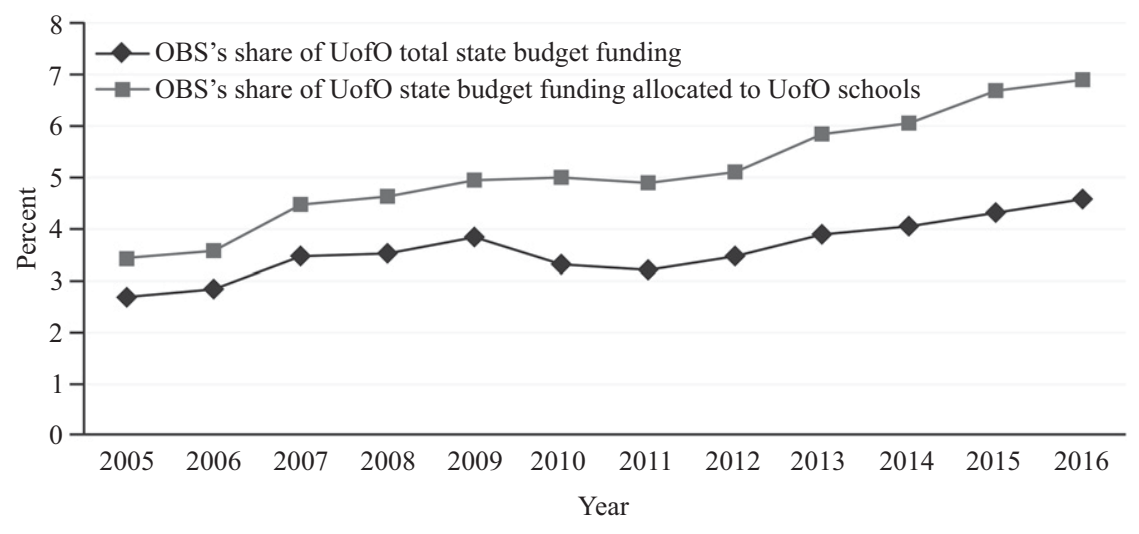

OBS's position prior to entering the international accreditation process).

\section{First Attempts in the Pursuit of Accreditation (2008-2009)}

"Based on several estimates, the number of business schools in the world has exceeded 12,000. All these schools claim to be the 'top' or close to the top. In order to survive in this competition, our only chance is to gain an international stamp of approval from one of the major accreditation agencies. This would advance our school to be among the top 500 institutions in the world."-OBS dean, Speech, 2007
Having witnessed the arrival of AACSB and EQUIS to the Finnish (and European) business school scene, it did not take long for OBS's dean to learn about the type of leverage that could be offered by international accreditations. After reasoning that EQUIS's ethos and standards were better suited to a Nordic business school, in 2007, OBS initiated preparations to apply for EQUIS eligibility. Consequently, the internationalization of the faculty and student body became a key issue. Parallel to the Ministry's incentives for higher education internationalization, OBS's degree program portfolio was complemented by two new international

TABLE 2

OBS's Position Prior to International Accreditation

\begin{tabular}{|c|c|c|c|}
\hline & Legitimacy & Status & Reputation \\
\hline $\begin{array}{l}\text { Global (judged in relation } \\
\text { to business school field) }\end{array}$ & $\begin{array}{l}\text { OBS is a non-accredited, } \\
\text { internationally invisible } \\
\text { school }\end{array}$ & $\mathrm{n} / \mathrm{a}$ & $\mathrm{n} / \mathrm{a}$ \\
\hline $\begin{array}{l}\text { Finland (judged in relation } \\
\text { to Finnish university-based } \\
\text { business schools) }\end{array}$ & $\begin{array}{l}\text { OBS has been a degree- } \\
\text { granting institution since } \\
1990\end{array}$ & $\begin{array}{l}\text { OBS is a low-ranked } \\
\text { degree-granting business } \\
\text { school }\end{array}$ & $\begin{array}{l}\text { OBS is an overachiever in } \\
\text { undergraduate and graduate } \\
\text { degree production; research } \\
\text { output is relatively low }\end{array}$ \\
\hline $\begin{array}{l}\text { University of Oulu (judged } \\
\text { in relation to schools } \\
\text { within the university) }\end{array}$ & $\begin{array}{l}\text { OBS has had a school status } \\
\text { within the University of Oulu } \\
\text { since } 2000\end{array}$ & $\begin{array}{l}\text { OBS is the youngest, } \\
\text { smallest and most } \\
\text { weakly resourced school }\end{array}$ & $\begin{array}{l}\text { OBS is an overachiever in } \\
\text { undergraduate and graduate } \\
\text { degree production and an } \\
\text { underachiever in research } \\
\text { and doctoral degree production. }\end{array}$ \\
\hline $\begin{array}{l}\text { Oulu Business School } \\
\text { (judged in relation to } \\
\text { departments within } \\
\text { the school) }\end{array}$ & $\begin{array}{l}\text { OBS is a school that is a part } \\
\text { of a large public university } \\
\text { offering undergraduate, } \\
\text { graduate and doctoral degrees }\end{array}$ & $\begin{array}{l}\text { Ranking among } \\
\text { disciplinary-structured } \\
\text { departments determined } \\
\text { based on department size } \\
\text { (Marketing and Accounting } \\
\text { are largest) }\end{array}$ & $\begin{array}{l}\text { Marketing and Accounting } \\
\text { departments are efficient } \\
\text { undergraduate and graduate } \\
\text { degree producers; research } \\
\text { output is relatively high }\end{array}$ \\
\hline
\end{tabular}


master's programs that increased the proportion of international degree-seeking students. These actions were followed by the establishment of a new department, International Business, the opening of bachelor's level admissions to finance majors, and the founding of the Martti Ahtisaari Institute of Global Business and Economics (MAI), a research and educational institute supported by the Nobel Peace Prize Laureate and former President of Finland that aimed to enhance the school's international reach and recognition. In the opening seminar of the Institute and in the presence of President Ahtisaari, the university rector, and board, the dean declared:

It is not news that the global competition between business schools is getting tougher and tougher. There are altogether 12,000 business schools in the world that are competing globally for prestige, students, research publications, and funding. Oulu Business School has already reached the top of the world in certain areas of research; however, as a whole, we still have a lot to develop. Our goal is first to be among the top 500 business schools in the world, and later among the top 100 (OBS dean's speech at the MAI's opening ceremony, April 25, 2008).

However, the ambitious words about global positioning and pursuing major international accreditations (meaning both EQUIS and AACSB) quickly ran counter to the more mundane organizational realities of OBS. Upon detailed examination of the EQUIS standards, serious concerns were raised about the program's inclusion-exclusion criteria. In general, accreditation agencies expect an accreditation-seeking school to be a wellestablished, clearly defined entity in which quality is consistent across the institution in all of its programs. In practice, these criteria mean that to become accredited, a business school must have control over all of its university's business programs. Consequently, at the UofO, this requirement brought the university's executive MBA program, administered by the Continuing Education Centre (CEC), into the spotlight.

Although the eMBA program was administratively distinct from the discipline-based MSc programs offered by OBS, it was unquestionably a business degree. Having recruited most its faculty from OBS, it was likely that neither EQUIS nor AACSB would accept eMBA's exclusion from the accreditation review. As a result, OBS aimed to move the eMBA program from the CEC to OBS. At the CEC, these endeavors faced heavy resistance, as the eMBA program was the unit's primary profit generator.
Although OBS's management also viewed the move as necessary in terms of further developing the program, special urgency was generated by the school's accreditation aspirations. In early September 2008, OBS argued in its meeting with CEC representatives that

OBS considers it extremely important that the eMBA program be included in the school's accreditation process. The accreditation of the eMBA program as a part of OBS is essential for the future development and success of the program. According to our estimates, eMBA does not, in its current format, fulfill the international accreditation criteria, as a response to which significant changes to the program's administration, finances, and contents must be made. Implementing these changes outside OBS is, in light of the accreditation requirements, practically impossible (Meeting Memo, September 9, 2008).

Within the university, eMBA program's governance became subject to heavy and long-lasting disputes. From OBS's perspective, the prolonged decision-making process was interpreted as the university's failure to see the importance and urgency of accreditation for the business school. In anticipation of a solution to the eMBA issue, OBS submitted its EQUIS eligibility application in late 2008. Although the decision to transfer the eMBA program to OBS was finally achieved after aggressive lobbying and meetings with the UofO Board representatives, regrettably, it occurred just days after EQUIS made its decision to reject OBS's application. In the decision letter received by the dean in June 2009, OBS was evaluated as having failed to achieve a sufficient level of corporate connections and internationalization. Although no explicit reference to the eMBA issue was made by the EFMD, internally, the episode left OBS skeptical of the university-level support for the accreditation process.

\section{The First Breakthrough (2010-2011)}

In OBS's initial, bold statements, its aim was to "get internationally accredited." At the time, EQUIS and AACSB accreditations were considered equally desirable. In fact, many school communications implied that both accreditations were on the agenda and that eventually OBS would try to achieve both. As mentioned previously, OBS was a European business school, so there were numerous presumptions in favor of starting with EQUIS. In its public communications, EFMD portrayed EQUIS as a European accrediting body with a great deal of 
tolerance for diversity. AACSB, in contrast, was viewed by OBS as a thoroughly American framework, with little understanding of the Finnish education system. But, the setbacks experienced with the attempted EQUIS accreditation left OBS's dean doubtful of the school's ability to obtain it. However, with the level of dedication having already been built, abandoning the accreditation project was not an option. Furthermore, the vagueness of the EQUIS rejection letter raised the question of whether the decision by EFMD was political and based on the OBS's arguably low status rather than on its recent performance/improvements.

Frustrated by the EQUIS responses, OBS decided to familiarize itself with AACSB accreditation, which was rather new in the Nordic countries (by 2008, only Aalto was accredited). Shortly thereafter, OBS applied for AACSB International membership, which was granted in the spring of 2010. The quick acceptance decision was followed by the preparation of the AACSB eligibility application. At the same time, its first experience seeking international accreditation had educated OBS's management regarding the time-consuming and costly nature of the accreditation process. As a response, the school decided to apply for funding for the project from the European Regional Development Fund (ERDF).

After the resolution of the eMBA issue, the university's internal power relations found a new expression in the ERDF funding application process. By definition, ERDF is EU funding directed to structural development projects that promote economic and social cohesion between the different regions within the European Union. ERDF funding is allocated regionally based on national-level strategies. Before submitting an application, the applying faculty or unit must consult with its mother university and ensure that a certain percentage of the total project budget will be covered by the university's self-financing as well as by municipal and private funding.

At the University of Oulu, ERDF applications are ranked and prioritized internally prior to a recommendation to send them on to the Council of the Oulu Region that coordinates the application process. Despite its fit with the aims of the ERDF funding strategy, at the university level, OBS's application was ranked low in priority. For example, the UofO funding evaluation council stated, "the regional effectiveness of the proposal is weak ... the proposal is not suitable for ERDF funding ... [OBS] should apply for funding from some other source" (UofO ERDF funding evaluation council, April 13, 2010). With leverage gained from local supporters, such as the City of Oulu, and some large business firms in the area, pressure was put on the university's headquarters to allow OBS to go forward with the application. Eventually, a favorable funding decision-EUR 800,000 in total-was obtained in the fall of 2010. The acquired funding enabled OBS to resource an accreditation team. Equally important, however, was the symbolic value of the project budget and the appointed team members, which legitimated the accreditation project not only within the school but also within the university.

"Furthermore, the vagueness of the EQUIS rejection letter raised the question of whether the decision by EFMD was political and based on the OBS's arguably low status rather than on its recent performance/ improvements."

The AACSB eligibility application was submitted and accepted in the summer of 2011. At the same time, OBS went through a change in the school's top management, when the dean, exhausted by the adversity involved in the accreditation project, decided to resign, and he was succeeded by the former vice dean. Under the new dean's leadership, OBS began to work with an AACSB mentor in the fall of 2011, concentrating on the mission alignment of OBS. This "reality check" with the mentor included an evaluation of the school's research performance and educational scope along with its mission statement. The research showed that according to the national-level journal classification system, the total number of top (level 3) and leading (level 2) publications produced by OBS was only six for that year (Figure 3). In terms of education, OBS was advised to articulate a mission that acknowledged the school's position among its national peers as well as regionally. As a result, the school was framed as a North Finland-based business school that recruited the majority of its students, faculty, and corporate partners from northern Finland. The final wording of the mission and vision statements was as follows:

Our Mission: We generate business competencies in cooperation with the scientific community, business partners and the larger society. We strive to develop expertise and foster the development of leadership qualities in our students. Through our actions and global mindset, we participate in the development of the economy, especially in northern Finland.

Our Vision: As part of the University of Oulu, we aspire to be an international, multidisciplinary, researchbased business school. 


\section{FIGURE 3}

\section{OBS's Levels 3, 2, and 1 Journal Articles 2005-2015}

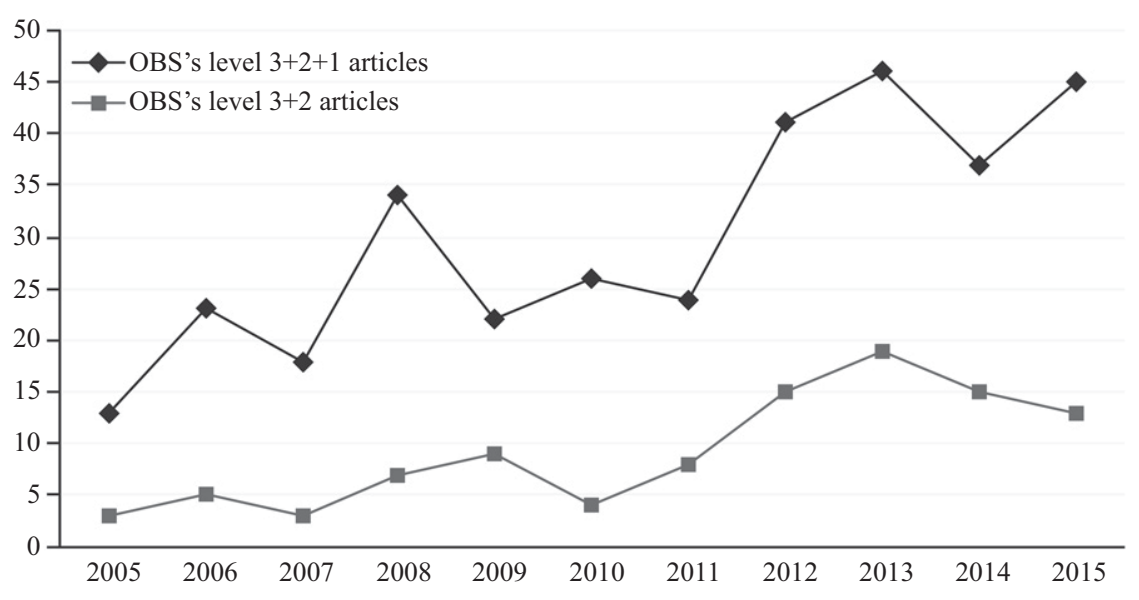

At the same time, the Finnish university sector was taking the first steps toward developing its own internal ranking system. At the beginning of 2011, the University of Turku (Research Unit for the Sociology of Education, RUSE) published a report that rated universities in terms of research and teaching productivity. This controversial report (authored by Kivinen et al., 2011) raised a heated discussion among Finnish universities as well as policymakers as to whether the report was methodologically rigorous and reliable or overly influenced by the authors' educational policy aspirations. After all, at the time, the funding formula for Finnish universities was under consideration by the Ministry of Education. OBS celebrated its $\mathrm{A}++$ rating, which underlined its relatively good performance visà-vis other degree-granting business schools and indicated that the school was "reaching an excellent international level."

More negative evaluations, such as the business school rankings published in Talouselämä business magazine 1 year later (Mikkonen, 2012), ranking OBS last among the 10 university-based business schools, were greeted with more critiques of the measurement system. Based on 13 criteria (one of which was accreditations received), the Talouselämä ranking positioned Aalto and Hanken at the top and the youngest institutions at the bottom. The controversial ranking was widely cited in marketing communications by the deans of the highly ranked business schools. OBS students did not let the results go unnoticed either. In her obviously disappointed but supportive feedback to the school, a representative of OBS's student association wrote,

OBS was ranked last, and I presume this will raise thoughts among the students as well as faculty and staff. The despair, however, will not pay off. Compared to the other schools, OBS is still ranked best in teaching efficiency and students' working life preparedness. So, apparently, we are doing something right. Even though there is a lot to improve, we should not give up! (Student representative, February 20,2012 ).

Acknowledging that internationalization was still a major area needing improvement, the dean reproached the magazine for using narrow measures and wrote in his response to students,

On behalf of OBS, here are my comments on the Talouselämä ranking. The article should be read thoroughly instead of just looking at the end result. The problem with rankings is, namely, that the selection of the measures has an enormous impact on the final outcome (OBS dean, e-mail to the student association, February 20, 2012).

\section{Accreditation Accomplished (2012-2013)}

Despite the promising start of the AACSB process, OBS management found it difficult to forget the time and devotion invested in attempting to obtain EQUIS accreditation. Hence, as soon as the 2-year ban against resubmitting an EQUIS eligibility application had passed, OBS decided to try again. Although it was aware of the difficulties involved in simultaneously pursuing two accreditations, OBS's 
management felt that there was little risk because the AACSB process was already well underway. After resubmitting the eligibility application and hosting another briefing visit in fall 2011, OBS was again denied eligibility by EQUIS. Again, the somewhat cursory explanation for the rejection revolved around the same alleged deficiencies (international operations and corporate connections) that had been raised in the first rejection letter 2 years earlier.

Convinced that applying for EQUIS again in the near future was no longer a feasible option, accreditation efforts were focused on improving OBS's activities in line with AACSB's standards. The AACSB Standards Alignment Plan (SAP), which identified OBS's performance with reference to AACSB's 2003 Standards, was submitted in August 2012. Characteristic of the traditionally open and cooperative relations among the business schools, the emerita rector of Hanken, who had pushed the school through the EQUIS process and had been involved in the school's AACSB eligibility efforts, was invited to visit OBS to advise the accreditation team. At the time of the invitation, the understanding at OBS was that Hanken was farther along in the AACSB process and would undoubtedly be accredited long before OBS.

In contrast to the experiences of most business schools, AACSB's Initial Accreditation Committee (IAC) accepted OBS's SAP without questions or concerns in October 2012, permitting the school to start preparing for the final Self Evaluation Report (SER) and peer review team (PRT) visit. After an intense period of collection of Assurance of Learning evidence and Intellectual Contributions data, the SER was finally submitted in May 2013. The PRT visit occurred in September and ended with a recommendation to the IAC that OBS be granted business accreditation. The formal decision on OBS's accreditation was made by the AACSB Board in November 2013.

The news about OBS's AACSB accreditation spread quickly among business schools in Finland, catching most of its peer schools by surprise. Especially among the schools that had already begun considering whether to apply, OBS's accreditation pushed the deans of non-accredited schools to place international accreditation on a more urgent agenda. In accredited institutions, some also started to highlight Aalto's "triple crown" status (i.e., the school is accredited by AACSB, EQUIS, and AMBA), thus emphasizing its position as the national flagship over OBS that was now accredited "only" by the AACSB.
Locally, OBS's accreditation was noted and commended in northern Finland's newspaper and by the City of Oulu. Within the university, the accreditation news was applauded among the faculties and especially among the top management. Suddenly, OBS was able to make headlines that benefitted the entire institution. The rector of the university praised the business school's achievement:

The accreditation gained by the Oulu Business School is a significant step in the university's internationalization process. It will help the recruitment of international students, researchers, and teachers and the establishment of joint research and study programs with highly recognized international universities. In the field of business studies, the accreditation is very important; however, it will benefit the entire university (University's rector, November 7, 2013).

\section{Impact of Accreditation on Reputation, Status, and Legitimacy (2013-2016)}

Three years have now elapsed since OBS's initial AACSB accreditation. Although the legitimacy, status, and reputation judgments of OBS's key constituents are difficult to measure because they take time to formulate and turn into concrete returns on investment, some short-term benefits of international accreditation are already visible. On the most important performance indicators used by the Ministry of Education, OBS degree production doubled and its research publications quadrupled between 2005 and 2015 (see Figures 3 and 4).

A part of the progression is undeniably attributable to general higher education policy changes and the implementation of stronger performance-based measures of publication and degree output in Finland since 2010. However, our findings contradict the critics' notion (e.g., Harvey, 2004) that accreditation increases the bureaucratic burden of business schools to the extent that it harms the faculty's core research and education activities. On the contrary, at OBS, the AACSB's Assurance of Learning requirements initiated degree reforms that streamlined the curricula and enhanced degree production. Furthermore, the explicit faculty qualifications criteria implemented as part of the process made the OBS faculty members more aware of their expected publication output.

During the time period under scrutiny here (2006-2016), OBS's share of the state budget funding allocated within the UofO grew from $3.4 \%$ in 2005 to $6.9 \%$ in 2016 (see Figure 2). At the national level, however, the steering effect of the Ministry's tightening 
FIGURE 4

\section{OBS's Performance on the Main Indicators}

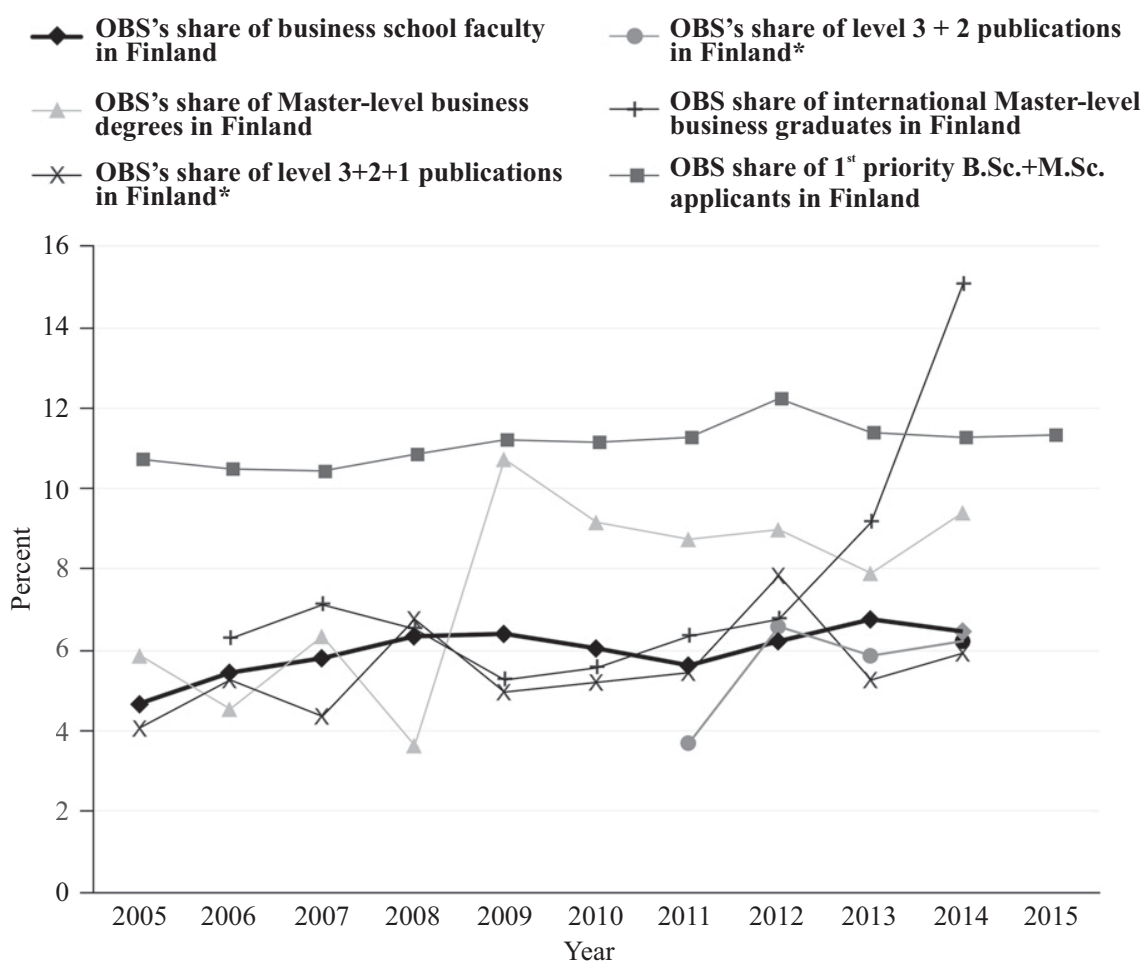

* Finnish 3-level journal classification system ( 1 = basic; 2 = leading; $3=$ top).

performance measures has led most business schools to improve their performance along the key indicators. In national comparisons, OBS has traditionally been efficient (even an overachiever) in undergraduate and graduate degree production, and it still is. In terms of research output, OBS is now average, indicating that top publications are still rare. Therefore, although the overall reputation judgments of OBS are likely to be positive, the efficiency in degree production can be easily downplayed based on the argument that OBS is still a teaching-emphasis school. As most evaluators in the field want to believe, the real and truly international prestige of a business school (or a university, for that matter) is what follows from research published in very select, highly prestigious scholarly outlets (Alvesson, 2013: 102; Spender \& Khurana, 2013).

Given the absence of a formal and systematic ranking system, any accreditation-driven rise of OBS in the pecking order of Finnish business schools is not easy to verify. According to a recent, rigorous scholarly analysis and ranking of Nordic business research output (number of ABS-AJG publications at the levels of $4^{*}, 4$ and 3 over the period from 2005-2015), however, OBS ranked relatively high in accounting and marketing (Sihvonen \& Vähämaa, 2015). Out of 90 identified academic institutions, OBS's accounting program was ranked 7th among the Nordic countries and 3rd in Finland, whereas its marketing positions were 11th and 4th, respectively.

Otherwise, analyses of the changes in OBS's competitive position vis-à-vis its peers led to ambiguous results. On the one hand, OBS's share of business school applicants at the national level has not increased in the years (2014-2016) immediately following the accreditation. On the other hand, small signs of OBS's improved status can be observed, because the obtained accreditation has not gone unnoticed among Finnish business schools. One clear outcome is that the international accreditation of a "low-ranked" business school created an understanding that gaining accreditation is a realistic goal for business schools that are not included in the "top two," initiating an AACSB race in Finland. Indeed, AACSB's member statistics indicate a significant increase in Finnish business schools' accreditation activities (see Finnish business schools' accreditations, eligibilities, and memberships in Table 3). Whereas a few years ago only two 
TABLE 3

Business School Accreditations in Finland (Sources: AACSB International website, EFMD website, universities' web pages.)

\begin{tabular}{llll}
\hline Year Founded & \multicolumn{1}{c}{ Business Schools in Finland } & \multicolumn{1}{c}{ Memberships } & \multicolumn{1}{c}{ Accreditations and Eligibilities } \\
\hline 1909 & Svenska Handelshögskolan (Hanken) & AACSB, EFMD, AMBA & EQUIS (2000), AMBA (2008), AACSB (2015) \\
1911 & Aalto University School of Business & AACSB, EFMD, AMBA & AMBA (1997), EQUIS (1998), AACSB (2007) \\
1927 & Handelshögskolan vid Åbo Akademi & AACSB & AACSB eligibility \\
1950 & University of Turku & AACSB & AACSB eligibility \\
1965 & University of Tampere & None & None \\
1966 & University of Vaasa & AACSB, EFMD & EPAS (2010) \\
1967 & University of Jyväskylä & AACSB, AMBA & AMBA (2012), AACSB eligibility \\
1991 & University of Oulu & AACSB, EFMD & AACSB (2013) \\
1991 & University of Lappeenranta & AACSB, EFMD & EPAS (2012) \\
2010 & University of Eastern Finland & AACSB & None \\
\hline
\end{tabular}

Updated June 4, 2018

Finnish AACSB member schools existed (Aalto and Hanken), in June 2018 there are 10 members, including eight university-based business schools (of the ten total schools) and two university of applied sciences-based schools (AACSB, 2018b).

I feel that OBS's accreditation has started a kind of race among the schools, and people are thinking, "who will be next" [...] It might also very well be that not all of the university-based business schools will be able to get the accreditation initially, which makes the race more hectic for the ones wanting to be next in line (OBS dean, interview, January 5, 2015).

OBS's improved positioning has also become apparent in other schools' appreciation of its accreditation experience. Since gaining accreditation, individuals involved in the OBS accreditation project have been active in consulting with other schools in Finland (and in neighboring countries). Furthermore, of OBS's dean was appointed to significant positions of trust as the chair of the Association of Finnish Business Schools and the chairman of a group designing the structural renovation of the national business school field upon invitation by the Finnish University Rectors' Council.

Somehow, I feel that by gaining the accreditation, OBS leaped into the proximity of Aalto and Hanken with regard to the presence and standing of our school within the Finnish business school community [...] I think the accreditation achievement clearly played a part in these appointments (OBS dean, interview, January 5, 2015).

As a response to joining the AACSB community of accredited institutions, OBS has seen increasing interest in the school in the form of various partnerships, such as joint degree proposals. Although AACSB-accredited schools are more inclined (due to the AACSB criteria) to cooperate with one another than with outsiders, this could clearly indicate OBS's acceptance as a legitimate global actor. As of 2016, OBS has not re-applied for EQUIS accreditation. Instead, during the first years after achieving AACSB accreditation, many of OBS's efforts have been directed toward utilizing the benefits and opportunities of accredited school status.

Before accreditation, even though we already had a network of international partners, the discussions of new initiatives with high-level partners were typically more small talk-type discussions. [...] Now, we get concrete cooperation offers for setting up double degrees, exchange programs and so on-and these proposals come in streaming, and already, we have taken action on some. And this did not happen before we got the accreditation" (OBS dean, interview, January 5, 2015).

The impact of international accreditation on OBS's position in terms of reputation, status, and legitimacy (3 years after obtaining the AACSB accreditation) is summarized in Table 4.

\section{DISCUSSION AND CONCLUSIONS}

Although many have noted and expressed concern about the increased competition within the global field of management education, few have identified the type of rivalry that exists between business schools as specifically positional competition. In this type of competition, winning means climbing up in the rather permanent status hierarchy of business schools that is created and constantly reproduced 
TABLE 4

Influence of Accreditation on OBS's Position

\begin{tabular}{|c|c|c|c|}
\hline & Legitimacy & Status & Reputation \\
\hline $\begin{array}{l}\text { Global (judged in relation } \\
\text { to business school field) }\end{array}$ & $\begin{array}{l}\text { OBS has been an AACSB- } \\
\text { accredited school since } 2013\end{array}$ & $\begin{array}{l}\text { OBS is a newly accredited } \\
\text { school }\end{array}$ & $\begin{array}{l}\text { OBS's research output is } \\
\text { moderate; A-level publications } \\
\text { are still rare }\end{array}$ \\
\hline $\begin{array}{l}\text { Finland (judged in relation } \\
\text { to Finnish university-based } \\
\text { business schools) }\end{array}$ & $\begin{array}{l}\text { OBS has been a degree-granting } \\
\text { institution since } 1990\end{array}$ & $\begin{array}{l}\text { OBS is a mid-ranked } \\
\text { degree-granting business } \\
\text { school }\end{array}$ & $\begin{array}{l}\text { OBS is an overachiever in } \\
\text { undergraduate and graduate } \\
\text { degree production; research } \\
\text { output is average }\end{array}$ \\
\hline $\begin{array}{l}\text { University of Oulu (judged in } \\
\text { relation to schools within } \\
\text { the university) }\end{array}$ & $\begin{array}{l}\text { OBS has had a school } \\
\text { status within the University } \\
\text { of Oulu since } 2000\end{array}$ & $\begin{array}{l}\text { OBS is a weakly resourced } \\
\text { school }\end{array}$ & $\begin{array}{l}\text { OBS is an overachiever in } \\
\text { undergraduate and graduate } \\
\text { degree production and is } \\
\text { below average in research and } \\
\text { doctoral degree production. }\end{array}$ \\
\hline $\begin{array}{l}\text { Oulu Business School } \\
\text { (judged in relation to } \\
\text { departments within the } \\
\text { school) }\end{array}$ & $\begin{array}{l}\text { OBS is a full-service business } \\
\text { school offering undergraduate, } \\
\text { graduate, doctoral, and eMBA } \\
\text { programs since } 2010\end{array}$ & $\begin{array}{l}\text { Ranking among } \\
\text { disciplinary-structured } \\
\text { departments influenced } \\
\text { by AACSB AQ/PQ } \\
\text { requirements (Marketing, } \\
\text { Accounting and Management } \\
\text { \& International Business are } \\
\text { the best performers) }\end{array}$ & $\begin{array}{l}\text { Maintenance of AACSB } \\
\text { accreditation requires } \\
\text { continuous improvement of } \\
\text { AQ/PQ criteria, which form a } \\
\text { basis for evaluating the } \\
\text { performance of individuals } \\
\text { and disciplinary-structured } \\
\text { departments }\end{array}$ \\
\hline
\end{tabular}

based on the institutions' characteristics (e.g., age, location, and historical background) and performance (e.g., student selectivity and scientific prestige) and formal recognitions of their excellence (e.g., accreditations and rankings). Losing, on the other hand, means falling down the same ladder, which will occur automatically if one stops climbing up or climbs too slowly, letting others climb past. For the institutions involved, this means a zero-sum game: Unlike in business markets, blue oceans (Kim \& Mauborgne, 2005), or “Ansoff's windows" (Ansoff, 1965) simply do not exist for business schools.

We sought to answer the question, "How does international accreditation affect business school competition? Through a detailed analysis of Finlandbased Oulu Business School's accreditation process, we were able to conclude that the expansion of the two major international accreditation agencies, AACSB and EQUIS, has been very much fueled by business schools' motivations to not only improve quality, but also to enhance their legitimacy, status, and reputation. In other words, AACSB and EQUIS are successful particularly because of the opportunities they create for business schools to move upward in the status hierarchy. Thus, although both accreditation agencies frame their core missions around improving the quality of management education, paradoxically, they reinforce a positional competition that overemphasizes the ends (accreditation labels) over the means (quality improvement).

"Thus, although both accreditation agencies frame their core missions around improving the quality of management education, paradoxically, they reinforce a positional competition that overemphasizes the ends (accreditation labels) over the means (quality improvement)."

Facilitated by international accreditations, the positional competition among business schools transforms national business school systems. In Finland, OBS's accreditation process is part of a bigger picture in which the traditionally collaboration-based and rather homogeneous business school field is restructuring itself into a ranking-based system that is vertically aligned in three clearly distinguishable groupings: national elite business schools, aspiring universitybased mid-range schools, and teaching-oriented polytechnics. The top-tier schools include the two oldest, the currently triple-crown accredited capital city-based schools, Aalto and Hanken that have also established reasonably well-known positions internationally. On the bottom tier is the high-volume undergraduate education provided by the universities of applied sciences (formerly polytechnics). These institutions are typically marked by rural locations, a teaching focus, quasicommercial research projects, and, consequently, a low 
positional value. However, there are some signs that not all such schools are resigned to their fate; instead, they are eagerly trying to improve their positions by applying for program-based accreditations such as EPAS. Furthermore, two universities of applied sciences are members of AACSB, and three are members of EFMD. Finally, in the middle zone are the rest of the universitybased business schools (OBS included), a grouping within which the accreditation race is currently experienced most strongly.

Seeking competitive advantage through an accreditation-facilitated climb up the status hierarchy has important implications for the organizationallevel experience of the accreditation process. In the case of OBS, it became crucial to get started with and to accomplish the project rapidly, before other schools in Finland could jump on the "accreditation bandwagon." Although the accreditation process could eventually be associated with improvements in actual performance, educational quality emerged more as a by-product than as the ultimate goal of the initial accreditation process. Based on the accreditation race initiated by OBS's AACSB accreditation in Finland, the role played by the accreditation agencies in the increased and more visible positional competition among business schools is evident. For OBS, and presumably for many other eligibility and initial accreditation-seeking schools, the accreditation process became from early on a very clearly articulated exercise of defining the boundaries of the business school and establishing itself as a free-standing, competitive entity in both its university and national environments.

Although the accreditation process is often emphasized by AACSB and EQUIS as a development project, on the flip side of the coin is a more serious and even "corporate-like" redefinition of organizational rules and boundaries: What is our mission, and what is it that makes us distinctive? Who are we as a school, and where do we stand in relation to our peer schools? Against whom should we benchmark ourselves? Who should we partner with, and who are we competing against? For the collegially operating Finnish business schools where the faculty is accustomed to open information-sharing and is loyal first and foremost to their intellectual community (rather than to organizational boundaries and the entities that formally employ them), these changes represent a very different view of a business school.

At the societal level, increased corporatization and competition means the gradual abandonment of some traditional equalitarian principles organizing higher education and the transformation of Finland from a nonranking society to a ranking society (Välimaa, 2010). Although accreditation is essentially a system of rating (evaluating the performance of a school against a rather explicit standardized framework), not ranking (evaluating schools' performances against each other using more or less implicit criteria), possessing these quality labels forms a basis for rankings in itself. Following the logic of positional competition, the potential benefits of international accreditation for a low-status business school are more remarkable than those for a school that is higher in the status hierarchy. Furthermore, the benefits also depend on how accreditation-saturated the business school field is.

Regrettably, while more and more schools will obtain accreditations, the benefits of the lengthy accreditation process quickly transform from a source of competitive advantage to a basic competitive requirement. In a pessimistic scenario, this could guide business schools, particularly those in accreditation-saturated countries and regions, to view accreditations neither as a quality improvement nor competitive advantage, but simply as a necessity, which might lead accreditation agencies away from accomplishing their articulated missions of quality improvement. In the post-2008 Financial Crisis era, both AACSB and EQUIS (EFMD) play key roles in advancing ethics, social responsibility, and sustainability in management education globally. The conceivable inability of these organizations to stay interesting to business schools and to live up to their missions might put the entire society at a disadvantage: Thinking backward, if there were no longer either strict national-level regulation or AACSB or EQUIS, who or what would regulate the business schools? Would there be anything else but rankings? Where would the business schools who have arguably already lost their way (Bennis \& O’Toole, 2005; Khurana, 2007) head then?

\section{APPENDIX A}

\section{Data and Methodology}

The focal study explores the accreditation endeavors of Oulu Business School (OBS) in Finland, which took place from 2006-2016. We argue that the OBS case is particularly revealing because it provides the opportunity to observe the process of international accreditation in a context that is relatively new to accreditations. At the outset, gaining 
accreditation made the school one of the first AACSBaccredited institutions not only in Finland, but also in the Nordic countries. Considering the initially low status of the school, the relative competitive advantage available for OBS through international accreditation was remarkable and rather unique in its context.

In the spirit of Yin (1984, see also Bryman \& Bell, 2015), OBS also represents a revelatory case because it portrays a type of phenomenon that appears to have been previously inaccessible to scientific investigation. Indeed, the accreditation insiders (i.e., deans, quality directors, and accreditation managers) are typically administrators who generally do not conduct scholarly research. Conversely, for insiders among the faculty, it is likely that accreditation exercises fail to serve their research interests completely or by providing only occasionally interesting and partially publishable "research findings.” In our case, the authors' experiences with accreditation management are combined with their scholarly interests in studying business schools more generally.

The primary research method during the accreditation process was self-ethnographical (see Alvesson, 2003), as all three authors of this essay were actively involved in OBS's accreditation process. Because self-ethnography is commonly used for the study of higher education institutions (Willmott, 2003; Boud et al., 2006; Di Domenico \& Philips, 2009; Bryman \& Lilley, 2009), the data collection and analysis have taken place retrospectively, yet they follow an iterative reflection: The case has informed our search for relevant theories that have enabled us to specify and contextualize it (Siggelkow, 2007). Furthermore, in self-ethnographic studies, instead of participant observation, it is more appropriate to describe the researcher's role as that of observing participant. In our case, all of us were-quite naturally-primarily preoccupied by our administrative roles as a dean, a head of accreditation, and an accreditation coordinator. Therefore, participation always came first and was only occasionally or retrospectively complemented with observation or debriefing in a research-oriented sense (Alvesson, 2003).

Despite the iterative, abductive research approach applied (Dubois \& Gadde, 2002), being an insider to an organization being studied has both advantages and potential shortcomings. Sometimes insider research is disqualified because it is perceived as not exercizing intellectual rigor due to the researchers' personal stakes and emotional connections in the setting (Morse, 1998). This view has been countered, for instance, by Brannick and Coghlan (2007: 72), who argued that "insider research is not problematic in itself and is respectable research in whatever paradigm it is undertaken." On the positive side, being insiders provides us a clearer understanding of the research settings under scrutiny, including the organizational history, culture, and language of the business school. Unlike in traditional ethnographic studies where the researcher struggles to "break in" to a setting, the selfethnographer's challenge is the opposite: distancing oneself from the setting and "breaking out" from the taken-for-granted organizational context and one's fellow organizational members (Alvesson, 2003; Coghlan, 2007, Karra \& Phillips, 2008).

Breaking out from the OBS context and overcoming some obvious weaknesses of the self-ethnographic method (Alvesson, 2003), however, has been possible due to a number of changes enabling us to gain distance and obtain perspective on lived reality. First and perhaps most important, two authors have left OBS and continued their professional careers, including accreditation work and related research projects with other business schools. Second, the period under scrutiny allows us retrospective sense-making of the accreditation process. During this time, we have been able to reinforce and openly clarify our roles as researchers as opposed to those of self-ethnographic insiders. This made it possible and more credible to approach our fellow organizational members and former colleagues with interviews and informal discussions on the topic of accreditation.

In addition to the interviews, informal discussions, and our observations as participants, our longitudinal analysis of the OBS accreditation process builds on various written communications, including internal meeting memos, e-mail correspondence, and OBS accreditation documents, which were accessed by each author in the course of "normal organizational life" at OBS (see Appendix B). Although studying past events where the researchers themselves have taken part also involves retrospective interpretation that is potentially biased, we have actively tried to overcome the bias by prioritizing primary sources (e.g., meeting memos) over researchers' own memories of events. Therefore, the author who was least involved in particular events and meetings conducted the analysis of the related documents. In the analysis, a timeline of key events, related meetings, and e-mails was formed, which made it possible to formulate more accurate reconstructions of the discussion sequences that had taken place and decisions that had been made by the business school studied.

Finally, we accessed statistics, OBS annual reports and marketing materials, websites, social media, magazine and newspaper articles, and scholarly publications that helped us to elaborate both the OBS case and the Finnish business school field more thoroughly. Based on the national-level higher education databases accessible through the Ministry of Education, we were able to create time series (Figures 1-4) of OBS's performance in the key indicators, including publication output, degree production, student admissions, and funding. The data sources used in the study of the OBS accreditation process are listed in Appendix B. 
APPENDIX B

OBS Accreditation Process and Data Sources

\begin{tabular}{|c|c|c|c|c|c|}
\hline & \multicolumn{5}{|c|}{ OBS Accreditation Process (2006-2016) } \\
\hline & $\begin{array}{c}\text { The Youngest of the } \\
\text { Youngest } \\
(2006-2007)\end{array}$ & $\begin{array}{l}\text { First Attempts in the } \\
\text { Pursuit of } \\
\text { Accreditation } \\
\text { (2008-2009) }\end{array}$ & $\begin{array}{c}\text { The First } \\
\text { Breakthrough } \\
\text { (2010-2011) }\end{array}$ & $\begin{array}{c}\text { Accreditation } \\
\text { Accomplished } \\
\text { (2012-2013) }\end{array}$ & $\begin{array}{l}\text { The Impact of } \\
\text { Accreditation } \\
(2013-2016)\end{array}$ \\
\hline \multirow[t]{4}{*}{ Key events } & $\begin{array}{l}\text { New dean } \\
\quad \text { appointed } 2006\end{array}$ & $\begin{array}{l}\text { MAI established } \\
2008\end{array}$ & $\begin{array}{l}\text { ERDF funding } \\
\text { received } 2010\end{array}$ & $\begin{array}{c}\text { Talouselämä ranking } \\
\text { published } 2012\end{array}$ & $\begin{array}{l}\text { Informal group of } \\
\text { Nordic AACSB- } \\
\text { accredited schools } \\
\text { established } 2014\end{array}$ \\
\hline & $\begin{array}{l}\text { Familiarizing with } \\
\text { EQUIS standards } \\
2007\end{array}$ & $\begin{array}{l}\text { New international } \\
\text { master's programs } \\
\text { 2008; eMBA } \\
\text { program dispute } \\
\text { started } 2008\end{array}$ & $\begin{array}{l}\text { AACSB eligibility } \\
\text { and mentor } \\
\text { appointment } \\
2011\end{array}$ & $\begin{array}{l}\text { AACSB-accreditation } \\
\text { obtained } 2013\end{array}$ & $\begin{array}{l}\text { Hanken AACSB } \\
\text { accredited } 2015\end{array}$ \\
\hline & $\begin{array}{l}\text { Aalto AACSB } \\
\text { accredited } 2007\end{array}$ & $\begin{array}{l}\text { EQUIS data sheet } \\
\text { submitted 2008; } \\
\text { 1st EQUIS briefing } \\
\text { visit } 2009\end{array}$ & $\begin{array}{l}\text { New dean } \\
\text { appointed 2011; } \\
\text { University } \\
\text { productivity } \\
\text { report published } \\
2011\end{array}$ & & $\begin{array}{l}\text { Business research } \\
\text { ranking published } \\
2015\end{array}$ \\
\hline & & $\begin{array}{l}\text { 1st EQUIS rejection } \\
2009\end{array}$ & $\begin{array}{l}\text { 2nd EQUIS } \\
\text { application, } \\
\text { briefing visit, and } \\
\text { rejection } 2011\end{array}$ & & \\
\hline
\end{tabular}

Data Sources (2005-2016)

\begin{tabular}{|c|c|c|c|c|c|}
\hline $\begin{array}{l}\text { Accreditation } \\
\text { applications and } \\
\text { AACSB/EQUIS } \\
\text { correspondence }\end{array}$ & - & $\begin{array}{l}\text { EFMD: Membership } \\
\text { application and } \\
\text { decision; EQUIS } \\
\text { Eligibility } \\
\text { applications and } \\
\text { decisions; related } \\
\text { email } \\
\text { correspondence }\end{array}$ & $\begin{array}{l}\text { AACSB: } \\
\text { Membership } \\
\text { application and } \\
\text { decision; } \\
\text { Eligibility } \\
\text { application and } \\
\text { decision; related } \\
\text { email } \\
\text { correspondence }\end{array}$ & $\begin{array}{l}\text { AACSB: SAP and } \\
\text { decision letter; } \\
\text { SER and decision } \\
\text { letter; PRT chair } \\
\text { pre-visit letter; PRT } \\
\text { visit } \\
\text { documentation } \\
\text { and decision letter; } \\
\text { related e-mail } \\
\text { correspondence }\end{array}$ & $\begin{array}{l}\text { Presentations at } \\
\text { AACSB events; } \\
\text { Continuous } \\
\text { Improvement } \\
\text { Review (CIR) } \\
\text { Application; } \\
\text { related email } \\
\text { correspondence }\end{array}$ \\
\hline $\begin{array}{l}\text { Internal } \\
\text { accreditation } \\
\text { documentation } \\
\text { and } \\
\text { correspondence }\end{array}$ & $\begin{array}{l}\text { Memos and notes } \\
\text { (management } \\
\text { team, MAI board, } \\
\text { accreditation } \\
\text { team); Faculty \& } \\
\text { staff meeting } \\
\text { presentations; } \\
\text { Email } \\
\text { correspondence }\end{array}$ & $\begin{array}{l}\text { Memos and notes } \\
\text { (management } \\
\text { team, MAI board, } \\
\text { accreditation } \\
\text { team); Faculty \& } \\
\text { staff meeting } \\
\text { presentations; } \\
\text { Email } \\
\text { correspondence; } \\
\text { OBS-CEC meeting } \\
\text { memos (eMBA } \\
\text { program } \\
\text { governance) }\end{array}$ & $\begin{array}{l}\text { Memos and notes } \\
\text { (management } \\
\text { team, MAI board, } \\
\text { accreditation } \\
\text { team); Faculty \& } \\
\text { staff meeting } \\
\text { presentations; } \\
\text { Email } \\
\text { correspondence; } \\
\text { ERDF funding } \\
\text { application }\end{array}$ & $\begin{array}{l}\text { Memos and notes } \\
\text { (management } \\
\text { team, MAI board, } \\
\text { accreditation } \\
\text { team); Faculty \& } \\
\text { staff meeting } \\
\text { presentations; } \\
\text { Email } \\
\text { correspondence }\end{array}$ & $\begin{array}{l}\text { Memos and notes } \\
\text { (management } \\
\text { team, MAI board, } \\
\text { accreditation } \\
\text { team); Faculty \& } \\
\text { staff meeting } \\
\text { presentations; } \\
\text { Email } \\
\text { correspondence }\end{array}$ \\
\hline $\begin{array}{l}\text { Interviews and focus } \\
\text { groups }\end{array}$ & \multicolumn{5}{|c|}{$\begin{array}{l}\text { Emeritus rectors of Aalto and Hanken 2012; } \\
\text { AACSB directors and staff (former President John J. Fernandes 2014; OBS’s PRT Chair; OBS’s Liaison Officer); } \\
\text { OBS’s dean 2015, } 2016 \\
\text { Nordic AACSB-accredited schools' Accreditation Directors 2015; } \\
\text { Focus Group and email interviews: Nordic AACSB-accredited schools' Accreditation Directors } 2016\end{array}$} \\
\hline $\begin{array}{l}\text { Web pages } \\
\text { Annual reports }\end{array}$ & \multicolumn{5}{|c|}{ AACSB 2007-2018; EFMD 2005-2018 } \\
\hline
\end{tabular}


APPENDIX B

(Continued)

OBS Accreditation Process (2006-2016)

\begin{tabular}{ccccc}
\hline & First Attempts in the & & & \\
The Youngest of the & Pursuit of & The First & Accreditation & The Impact of \\
Youngest & Accreditation & Breakthrough & Accomplished & Accreditation \\
$(2006-2007)$ & $(2008-2009)$ & $(2010-2011)$ & $(2012-2013)$ & $(2013-2016)$
\end{tabular}

Statistics on Finnish Data from KOTA database 2005-2008 and Vipunen database 2009-2015; University of Oulu databases 2005-2015 business schools/ OBS

Studies and reports on Finnish business schools

Business Research in the Nordic Countries (Sihvonen, \& Vähämaa, 2015)

History of business schools in Finland (Alajoutsijärvi et al., 2012; Kettunen, 2013)

Talouselämä business magazine's ranking of Finnish business schools (Mikkonen, 2012)

Productivity of research and teaching in Finnish universities (Kivinen et al., 2011)

\section{REFERENCES}

AACSB. 2011. Globalization of management education: Changing international structures, adaptive strategies, and the impact of institutions. UK: Emerald.

AACSB, 2015. Eligibility procedures and accreditation standards for business accreditation.

AACSB 2016. About us. http://www.aacsb.edu/about. Accessed Sept. 16, 2016.

AACSB 2018a. AACSB-Accredited Universities and Schools. https://www.aacsb.edu/accreditation/ accredited-members/global-listing. Accessed June 4, 2018.

AACSB 2018b. Accredited Schools. https://www.aacsb.edu/ accreditation/accredited-members. Accessed June 4, 2018.

Adler, N. J., \& Harzing, A. 2009. When knowledge wins: Transcending the sense and nonsense of academic rankings. Academy of Management Learning $\&$ Education, 8: 72-95.

Alajoutsijärvi, K., Juusola, K., \& Lamberg, J.-A. 2014. Institutional logic of business bubbles: Lessons from the Dubai Business School mania. Academy of Management Learning \& Education, 13: 5-25.

Alajoutsijärvi, K., Kettunen, K., \& Tikkanen, H. 2012. Institutional evolution of business schools in Finland 1909-2009. Management \& Organizational History, 7: 337-367.

Alvesson, M. 2003. Methodology for close up studies: Struggling with closeness and closure. Higher Education, 46: 167-193.

Alvesson, M. 2013. The triumph of emptiness: Consumption, higher education, and work organization. Oxford, UK: Oxford University Press.
Ansoff, H. I. 1965. Competitive strategy. New York: McGraw-Hill.

Aspara, J., Lamberg, J.-A., Laukia, A., \& Tikkanen, H. 2011. Strategic management of business model transformation: Lessons from Nokia. Management Decision, 4: 622-647.

Bell, E., \& Taylor, S. 2005. Joining the club: The ideology of quality and business school badging. Studies in Higher Education, 30: 239-255.

Bennis, W. G., \& O'Toole, J. 2005. How business schools lost their way. Harvard Business Review, 83: 96-104.

Bitektine, A. 2011. Towards a theory of social judgments of organizations: The case of legitimacy, reputation, and status. Academy of Management Review, 36(1): 151-179.

Bitektine, A., \& Haack, P. 2015. The macro and the micro of legitimacy: Towards a multi-level theory of the legitimacy process. Academy of Management Review, 1: $49-75$.

Blanco Ramírez, F. 2015. International accreditation as global position taking: An empirical exploration of U.S. accreditation in Mexico. Higher Education, 69: 361-374.

Boud, D., Dahlgren, L.-O., Dahlgren, M. A., Larsson, S., Sork, T. J., \& Walters, S. 2006. Creating a 'world class' programme: Reciprocity and constraint in networked global collaboration. International Journal of Lifelong Education, 25: 609-622.

Brannick, T., \& Coghlan, D. 2007. In defense of being "native." The case for insider academic research. Organizational Research Methods, 10: 59-74.

Bryman, A., \& Bell, E. 2015. Business research methods. Oxford, UK: Oxford University Press.

Bryman, A., \& Lilley, S. 2009. Leadership researchers on leadership in higher education. Leadership, 3: 331-346. 
Casile, M., \& Davis-Blake, A. 2002. When accreditation standards change: Factors affecting differential responsiveness of public and private organizations. Academy of Management Journal, 45: 180-195.

Coghlan, D. 2007. Insider action research doctorates: Generating actionable knowledge. Higher Education, 54: 293-306.

Cooper, S., Parkes, C., \& Blewitt, J. 2014. Can accreditation help a leopard change its spots? Accounting, Auditing \& Accountability Journal, 2: 234-258.

DiDomenico, M., \& Philips, N. 2009. Sustaining the ivory tower: Oxbridge formal dining as organizational ritual. Journal of Management Inquiry, 18: 326-343.

Dillard, J. F., \& Tinker, T. 1996. Commodifying business and accounting education: The implications of accreditation. Critical Perspectives on Accounting, 7: 215-225.

Dubois, A., \& Gadde, L.-E. 2002. Systematic combining: An abductive approach to case research. Journal of Business Research, 55: 553-560.

Durand, R., \& McGuire, J. 2005. Legitimating agencies in the face of selection: The case of AACSB. Organization Studies, 2: 165-196.

EFMD 2016. EQUIS - EFMD Quality Improvement System Retrieved from https://www.efmd.org/accreditationmain/equis. Accessed Sept. 16, 2016.

Elliott, C. 2013. The impact of AACSB accreditation: A multiple case study of Canadian university business schools. Canadian Journal of Administrative Sciences, 3: 203-218.

Gioia, D. A., \& Corley, K. G. 2002. Being good versus looking good: Business school rankings and the Circean transformation from substance to image. Academy of Management Learning \& Education, l: 107-120.

Guillotin, B., \& Mangematin, V. 2015. Internationalization strategies of business schools: How flat is the world? Thunderbird International Business Review, 10.1002/ tie.

Flesher, D. L. 2007. The history of the AACSB International. Vol. 2: 1966-2006. Tampa, FL: AACSB International.

Frank, R. H. 1999. Higher education: The ultimate winner-take-all market? Ithaca, NY: Cornell University: ILR School.

Harvey, L. 2004. The power of accreditation: Views of academics. Journal of Higher Education Policy and Management, 2: 207-223.

Hazelkorn, E. 2014. Rankings and the global reputation race. New Directions for Higher Education, 168: 13-26.

Helms Mills, J., Weatherbee, T. G., \& Colwell, S. R. 2006. Ethnostatistics and sensemaking: Making sense of university and business school accreditation and rankings. Organizational Research Methods, 4: 491-515.

Henninger, E. A. 1998. Dean's role in change: The case of professional accreditation reform of American collegiate business education. Journal of Higher Education Policy and Management, 20: 203-213.

Hirsch, F. 1976. Social limits to growth. Cambridge, MA: Harvard University Press.

Iñiguez de Onzoño, S. 2011. The learning curve: How business schools are re-inventing education. New York: Palgrave Macmillan.

Jantzen, R. H. 2000. AACSB Mission-linked standards: Effects on the accreditation process. Journal of Education for Business, 75: 343-347.

Julian, S. D., \& Ofori-Dankwa, J. C. 2006. Is accreditation good for the strategic decision making of traditional business schools? Academy of Management Learning $\boldsymbol{\&}$ Education, 2: 225-233.

Juusola, K., Kettunen, K., \& Alajoutsijärvi, K. 2015. Accelerating the Americanization of management education: Five responses from business schools. Journal of Management Inquiry, 24: 347-369.

Karra, N., \& Phillips, N. 2008. Researching "back home” international management research as autoethnography. Organizational Research Methods, 11: 541-561.

Kettunen, K. 2013. Management education in a historical perspective: The business school question and its solution in Finland (Doctoral dissertation). Helsinki, Suomen Ekonomiliitto: Acta Societatis Oeconomorum.

Khurana, R. 2007. From higher aims to hired hands: The social transformation of American business schools and the unfulfilled promise of management as a profession. Princeton, NJ: Princeton University Press.

Kim, W. C., \& Mauborgne, R. 2005. Blue Ocean strategy: From theory to practice. California Management Review, 3: 105-121.

Kivinen, O., Hedman, J., \& Peltoniemi, K. 2011. Towards the best $A++$ rating productivity of research and teaching in Finnish universities. Research Unit for the Sociology of Education, RUSE. Turku, Finland: University of Turku.

LaFleur, E. K., Babin, L. A., \& Lopez, T. B. 2009. Assurance of learning for principles of marketing students: A longitudinal study of a course-embedded direct assessment. Journal of Marketing Education, 31: 131-141.

Lejeune, C., \& Vas, A. 2014. Institutional pressure as a trigger for organizational identity change: The case of accreditation failure within seven European business schools. In A. M. Pettigrew, E. Cornuel, \& U. Hommel, 
(Eds.), The institutional development of business schools. Oxford, UK: University Press.

Lowrie, A., \& Willmott, H. 2009. Accreditation sickness in the consumption of business education: The vacuum in AACSB standard setting. Management Learning, 4: 411-420.

Marginson, S. 2006. Dynamics of national and global competition in higher education. Higher Education, 52: 1-39.

Marginson, S. 2013. The impossibility of capitalist markets in higher education. Journal of Education Policy, 28(3): 353-370.

McKee, M. C., Mills, A. J., \& Weatherbee, T. 2005. Institutional field of dreams: Exploring the AACSB and the new legitimacy of Canadian business schools. Canadian Journal of Administrative Sciences, 4: 288-301.

McKenna, J. F., Cotton, C. C., \& Van Auken, S. 1995. Business school emphasis on teaching, research and service to industry: Does where you sit determine where you stand. Journal of Organizational Change Management, 8: 3-16.

Mikkonen, A. 2012. Kiitettävään on pitkä matka. Talouselämä, 7: 33-42.

Miles, M. P., Hazeldine, M. F., \& Munilla, L. S. 2004. The 2003 AACSB accreditation standards and implications for business faculty: A short note. Journal of Education for Business, 80: 29-34.

Morse, J. M. 1998. Designing funded qualitative research. In N. Denzin \& Y. Lincoln (Eds.), Strategies of qualitative inquiry. Thousand Oaks, CA: Sage.

Moskal, P., Ellis, T., \& Keon, T. 2008. Summary of assessment in higher education and the management of student-learning data. Academy of Management Learning \& Education, 2: 269-278.

Pesta, B. J., \& Scherer, R. F. 2011. The assurance of learning tool as predictor and criterion in business school admissions decisions: New use for an old standard? Journal of Education for Business, 86: 163-170.

Piazza, A., \& Castellucci, F. 2014. Status in organization and management theory. Journal of Management, 40(1): 287-315.

Podolny, J. M. 2009. The buck stops (and starts) at business school. Harvard Business Review, 87: 62-67.

Pringle, C., \& Michel, M. 2007. Assessment practices in AACSB accredited business schools. Journal of Education for Business, 82: 202-211.

Ridgeway, C. L., \& Walker, H. A. 1995. Status structures. In K. Cook, G. Fine \& J. House (Eds.), Sociological perspectives on social psychology: 281-310. Upper Saddle River, NJ: Pearson Education.

Rindova, V. P., Williamson, I. O., \& Petkova, A. P. 2010. Reputation as an intangible asset: Reflections on theory and methods in two empirical studies of business school reputations. Journal of Management, 36: 610-619.

Rindova, V. P., Williamson, I. O., Petkova, A. P., \& Sever, J. M. 2005. Being good or being known: An empirical examination of the dimensions, antecedents and consequences of organizational reputation. Academy of Management Journal, 48: 1033-1050.

Roller, R. H., Andrews, B. K., \& Bovee, S. L. 2003. Specialized accreditation of business schools: A comparison of alternative costs, benefits, and motivations. Journal of Education for Business, 78: 197-204.

Romero, E. J. 2008. AACSB accreditation: Addressing faculty concerns. Academy of Management Learning $\mathcal{E}$ Education, $7: 245-255$.

Scherer, R. F., Rajshekhar, G. J., Bryant, B., \& Tukel, O. 2005. Challenges of AACSB International accreditation for business schools in the United States and Europe. Thunderbird International Business Review, 6: 651-669.

Siggelkow, N. 2007. Persuasion with case studies. Academy of Management Journal, 50: 20-24.

Sihvonen, J., \& Vähämaa, S. 2015. Business research in the Nordic countries: An analysis of research outputs across countries, disciplines and institutions. Nordic Journal of Business, 64: 266-296.

Spender, J. C., \& Khurana, R. 2013. Intellectual signitures: Impact on relevance and doctoral programs. Disrupt or be disrupted. A blueprint for change in management education. San Francisco: GMAC, Jossey-Bass.

Suchman, M. C. 1995. Managing legitimacy: Strategic and institutional approaches. Academy of Management Review, 20: 571-610.

Swanson, D. L. 2004. The buck stops here: Why universities must reclaim business ethics education. Journal of Academic Ethics, 2: 43-61.

Thomas, L., Billsberry, J., Ambrosini, V., \& Barton, H. 2014. Convergence and divergence dynamics in British and French business schools: How will the pressure for accreditation influence these dynamics? British Journal of Management, 25: 305-319.

Thomas, H., Thomas, L., \& Wilson, A. 2013. Promises fulfilled and unfulfilled in management education. Bingley: Emerald Publishing.

Trank, C. Q., \& Rynes, S. L. 2003. Who moved our cheese? Reclaiming professionalism in business education. Academy of Management Learning \& Education, 2: 189-205.

Trapnell, J. E. 2007. AACSB International accreditation: The value proposition and a look to the future. Journal of Management Development, 1: 67-72. 
Urgel, J., 2007. EQUIS accreditation: Value and benefits for international business schools. Journal of Management Development, 1: 73-83.

Vidaver-Cohen, D. 2007. Reputation beyond the rankings: A conceptual framework for business school research. Corporate Reputation Review, 10: 278-304.

Washington, M., \& Zajac, E. J. 2005. Status evolution and competition: Theory and evidence. Academy of Management Journal, 48(2): 282-296.

Weber, M. 1978. Economy and society: An outline of interpretive sociology. In G. Roth \& C. Wittich (Eds.). Berkeley: University of California Press.

Willmott, H. 2003. Commercialising higher education in the UK: The state, industry and peer review. Studies in Higher Education, 28: 129-141.

Winston, G. C. 1999. Subsidies, hierarchy and peers: The awkward economics of higher education. The Journal of Economic Perspectives, 1: 13-36.

Winston, G. C. 2000. The Positional Arms Race in Higher Education. Williams Project on the Economics of Higher Education, Discussion Paper No. 54, April.

Winston, G. C. 2004. Differentiation among U.S. colleges and universities. Review of Industrial Organization, 4: 331-354.

Välimaa, J. 2010. The corporatization of national universities in Finland. In B. Pusser, K. Kempner, S. Marginson \& I. Ordorika (Eds.), Universities and the public sphere: Knowledge creation and state building in the era of globalization: 101-120. London: Routledge.

Yin, R. K. 1984. Case study research. Design and methods. Beverly Hills, CA: Sage.
Yunker, J. A. 2000. Doing things the hard way - Problems with mission-linked AACSB accreditation standards and suggestions for improvement. Journal of Education for Business, 75: 348-353.

Zammuto, R. F. 2008. Accreditation and the globalization of business. Academy of Management Learning $\&$ Education, 7(2): 256-268.

\section{$M$}

Kimmo Alajoutsijärvi works as a professor at the University of Jyväskylä, Finland, and at the University of Agder, Norway. Prof. Alajoutsijärvi's research interests are in management education, business cycles, and business relationships and networks. He is the former dean of Oulu Business School (2006-2011).

Kerttu Kettunen holds a doctoral degree from the University of Oulu, Finland (2013). She works currently as a postdoctoral researcher and accreditation manager at the Turku School of Economics, University of Turku, Finland. She worked as the accreditation manager of Oulu Business school in 2011-2014. Her research interests include history and institutional change of business schools.

Sauli Sohlo is the deputy director of the Martti Ahtisaari Institute and head of international accreditations at Oulu Business School, University of Oulu, Finland. He earned his MSc. at the University of Oulu in 1992. His current research concentrates on the development and competition of business schools, and business school accreditation. 
Copyright of Academy of Management Learning \& Education is the property of Academy of Management and its content may not be copied or emailed to multiple sites or posted to a

listserv without the copyright holder's express written permission. However, users may print, download, or email articles for individual use. 